\title{
Chrystologia filozoficzna Erica Voegelina
}

\author{
Tomasz Niezgoda \\ Instytut Religioznawstwa \\ Uniwersytet Jagielloński
}

\section{Abstract \\ The Philosophical Christology of Eric Voegelin}

The aim of this article is to investigate philosophical Christology in the works of Eric Voegelin. It seems that for Voegelin, in the person of Jesus Christ the so-called metaleptical structure of consciousness along with divine reality became luminous as present in every human being. What is more, divine reality (self-)revealed in the event of Christ as an eschatological movement of transfiguration. But the Voegelinian Christ is not the hypostatic union of God and man, but the full presence of divine reality in the consciousness of a man named Jesus. I conclude that Voegelinian Christology points to conditions of God's revelation: the appearance of God is limited by the metaleptical structure of consciousness and his own transcendence.

Key words: Christ, philosophical Christology, Eric Voegelin, metaxy, religious experience Słowa kluczowe: Chrystus, chrystologia filozoficzna, Eric Voegelin, metaxy, doświadczenie religijne

Termin „chrystologia filozoficzna” jest wysoce problematyczny ${ }^{1}$. Z jednej strony mamy bowiem do czynienia $\mathrm{z}$ dyscypliną teologiczną, której podstawą i zarazem horyzontem jest dogmat chrześcijański i prawdy wiary. W kontekście teologicznym: „Problem chrystologii w ścisłym znaczeniu tego słowa polega na określeniu stosunku pierwiastka boskiego i ludzkiego w Chrystusie"2, co niejako implikuje także - zarówno w porządku diachronicznym, jak i synchronicznym - uprzednie rozważenie

${ }^{1} \mathrm{~W}$ polskiej literaturze filozoficznej termin ten i związana z nim dyscyplina została spopularyzowana dzięki książce Xaviera Tilliette. Zob. X. Tilliette, Chrystus filozofów. Prolegomena do chrystologii filozoficznej, tłum. A. Ziernicki, Kraków 1996.

2 J.D. Kelly, Poczq̨tki doktryny chrześcijańskiej, tłum. J. Mrukówna, Warszawa 1998, s. 110. 
stosunku boskości Chrystusa do boskości Boga Ojca. Z drugiej strony jest filozofia, opierająca się na rozumie. Niemniej jednak istnieje taki rodzaj refleksji. Nie sprowadza się on jednak do omawiania „portretów Jezusa” występujących w różnych filozofiach. Taka refleksja schodzi głębiej i próbuje dotknąć bardziej fundamentalnych kwestii, częstokroć twierdząc, że w Chrystusie spotykają się - czy nawet wyłaniają - najważniejsze kategorie filozoficzne.

Głównymi dziełami, w których Eric Voegelin podejmuje temat Chrystusa i chrześcijaństwa, są czwarty tom jego monumentalnej serii Order and History - Order and History IV: The Ecumenic Age (konkretniej - wstęp do dzieła oraz rozdział The Pauline Vision of the Resurrected ${ }^{3}$ ) oraz obszerny artykut The Gospel and Culture. Należy zwrócić uwagę, że Voegelinowska ${ }^{4}$ analiza sensu i doniosłości chrześcijaństwa, a także osoby samego Chrystusa, opiera się na tekście biblijnym (przede wszystkim chodzi o Ewangelię Jana i Listy Pawłowe), z rozmysłem ignorując późniejszą tradycję teologiczną (patrystyczną) oraz wyznania wiary. Ewangelia dla Voegelina nie jest bowiem doktryną: człowiek (wierzący czy nie) w samym jądrze swojej egzystencji jest istotą poszukującą sensu. Wewnątrz samego chrześcijaństwa - ale podobnie i filozofii - tkwi wewnętrzne napięcie pomiędzy Ewangelią a jej doktrynalizacją. W rzeczywistości Ewangelia jest, według Voegelina, odpowiedzią na odwieczne ludzkie poszukiwanie sensu, zaś doktrynalizacja jest wypaczeniem tego sensu (w dalszej części tekstu czytelnik znajdzie odpowiedź na pytanie, dlaczego tak jest) ${ }^{5}$. W tym sensie Ewangelia jest odpowiedzią na pytanie wyrastające $\mathrm{z}$ egzystencjalnego niepokoju odnośnie do sensu i prawdy istnienia (w pewnym uproszczeniu można powiedzieć, że Voegelin rozumie prawdę podobnie do Edmunda Husserla: jako samoprezentację. Dlatego Voegelinowską ,prawdę egzystencji” można rozumieć jako prezentującą i ukazującą się rzeczywistość egzystencji). Nie można więc pytać o Chrystusa w pominięciu egzystencjalnego kontekstu. Ewangelia, będąca opowieścią o Jezusie Chrystusie, nie jest doktryną do nauczania czy wyuczenia, nie jest zestawem pewnych twierdzeń do przyjęcia, lecz opowieścią o boskim ruchu (divine movement), który dokonał się w osobie Jezusa Chrystusa ${ }^{6}$. Kiedy pisałem o tym, że Voegelin ignoruje

${ }^{3}$ E. Voegelin, Order and History IV: The Ecumenic Age, Columbia, Missouri, 2000, s. 45-107 oraz 303-339.

${ }^{4}$ Polski czytelnik poszukujący opracowań dotyczących filozofii Voegelina znajduje się w nieciekawej sytuacji. Właściwie wymienić można dwie znaczące pozycje będące zbiorami artykułów: Gnoza polityczna, J. Skoczyński (red.), Kraków 1998, która dotyczy przede wszystkim jego wczesnej koncepcji gnozy politycznej jako „immanentyzacji eschatonu”, oraz zbiór artykułów autorstwa zagranicznych autorów zatytułowany Problem ładu politycznego. Eseje o myśli Erica Voegelina, M.J Czarnecki, A. Miętek (red.), Warszawa 2010. Do najważniejszych światowych opracowań filozofii Voegelina w kontekście filozofii świadomości i religii należą: G. Hughes, Mystery and Myth in the Philosophy of Eric Voegelin, Columbia, Missouri, 1993; S.A. McKnight, Eric Voegelin's Search for Order in History, Baton Roque 1978. M.P. Morrissey, Consciousness and Transcendence: Theology of Eric Voegelin, Notre Dame, Indiana, 1994; E. Sandoz, The Voegelinian Revolution: A Biographical Introduction, Baton Roque, Louisiana, 1991; R.D. Srigley, Eric Voegelin's Platonic Theology: Philosophy of Consciousness and Symbolization in a New Perspective, New York 1991; E. Webb, Eric Voegelin: Philosopher of History, Seattle, Washington, 1981.

${ }^{5}$ E. Voegelin, The Gospel and Culture [w:] Published Essays 1966-1985, Baton Roque 1990, s. $174-175$.

${ }^{6}$ Ibidem, s. 190. 
kontekst teologiczny, poniekąd rozminąłem się z prawdą - właściwie Voegelin przez krytykę doktrynalizacji (przy której nie podaje ani konkretnych nazwisk, ani konkretnych poglądów) ustanawia chrześcijańską teologię chrystologiczną IV i V wieku jako negatywny punkt odniesienia dla swoich rozważań. Austriackio-amerykański myśliciel nie poddaje krytyce ani nicejsko-konstantynopolitańskiego credo czy chalcedońskiego wyznania wiary, ani arianizmu czy monofizytyzmu - dla niego bowiem każda $\mathrm{z}$ owych teologii jest wynikiem tego samego procesu doktrynalizacji, w którym Ewangelia zostaje oderwana od swojego egzystencjalnego i doświadczalnego kontekstu, jedynego, w jakim - zdaniem Voegelina - może być sensownie rozważana. Stąd też Voegelin odrzuca mówienie o Chrystusie w języku substancji, istoty, hipostazy czy zjednoczenia - to bowiem język teologiczno-metafizyczny, oderwany od wspomnianego kontekstu.

Podejmując tę tematykę w dziele autora Order and History, należy pamiętać, że nie można rozdzielić ,„[...] Voegelina [egzegety - przyp. T.N.] od Voegelina krytyka filozoficznego" .Według austriackiego myśliciela zarówno filozofia, jak i chrześcijaństwo (czy szerzej religia) dotyczą tej samej rzeczywistości. Religia - świadomość pneumatyczna według Voegelina - i filozofia - świadomość noetyczna - wyłaniają ze spotkania z „boską podstawą istnienia”. Innymi słowy, ostatecznie dotyczą one tego samego przedmiotu. Tym samym nie można zrozumieć sensu Voegelinowskiej chrystologii w oderwaniu od tego, co można nazwać jego ontologią, antropologią i filozofią Boga. Adekwatne zrozumienie Chrystusa Voegelina domaga się uwzględnienia filozoficznego horyzontu. Celem niniejszego artykułu jest nie tylko prezentacja oraz interpretacja chrystologii filozoficznejVoegelina, lecz także namysł, czy postać owej chrystologii nie wskazuje na coś innego poza sobą, coś równie fundamentalnego, co najpełniej nie ukazuje się właśnie w philosophia christus. W tym sensie celem artykułu nie jest próba polemiki z Voegelinem, ani też ujęcie jego chrystologii w kontekście porównawczym czy rozważenie, jak pewne tradycyjne problemy teologiczne są przez Voegelina rozwiązywane. Celem jest jedynie prezentacja podstaw owej chrystologii w uwzględnieniu kontekstu całości myśli autora Order and History oraz namysł nad tym, co motywuje takie a nie inne ujęcie tej problematyki. Cel ten jednak jest o tyle ambitny, że wiąże się z przedstawieniem znaczenia postaci Jezusa Chrystusa w kontekście całości filozofowania Voegelina - a więc konieczne staje się ukazanie, jak podstawowe kategorie filozoficzne spotyka się w Chrystusie.

Przy czym czytelnik musi mieć na uwadze fakt, że Voegelina można zaliczyć do tych dwudziestowiecznych filozofów, którzy za cel obrali sobie destrukcję czy też wyzwolenie się od tak zwanej metafizyki obecności ${ }^{8}$ (do nich zalicza się między

${ }^{7}$ B. Douglass, Okrojona Ewangelia. Krytyka Voegelinowskiej interpretacji chrześcijaństwa, thum. A. Polakowski [w:] Problem ładu politycznego. Eseje o myśli Erica Voegelina, A. Miętek, M.J. Czarnecki (red.), Warszawa 2010, s. 245.

${ }^{8}$ Termin „metafizyka obecności” nie pochodzi od Voegelina, lecz od Heideggera i Derridy. Voegelin woli mówić na przykład o dogmatycznym wykolejeniu (dogmatic dereilment) filozofii. Preferuję jednak termin Heideggerowski, ponieważ z jednej strony oddaje to, o co chodzi Voegelinowi, z drugiej natomiast poprzez fakt przejęcia tego terminu przez późniejszych filozofów - na przykład wspomnianych Derridę czy Mariona - wszedł on do powszechnego słownictwa. Przy czym pewne zamieszanie może budzić stosowanie przez Voegelina słowa obecność (presence) - autor Order and History, pisząc 
innymi Martina Heideggera, Jacques'a Derridę, Jeana-Luca Mariona). Dla każdego $\mathrm{z}$ tych filozofów owa obecność przyjmuje różną postać - dla Heideggera będzie to prymat teraźniejszości jako podstawowej temporalizacji czasu, dla Derridy - prymat tożsamości, sensu i logosu, a dla Mariona - prymat (niemyślanej) różnicy ontologicznej wobec donacji. Jak jest w przypadku Voegelina? Zdaniem Voegelina, filozofię, ale także teologię i myślenie religijne w ogóle, cechuje deegzystencjalizacja, czyli zapoznanie doświadczalnego kontekstu podstawowych pojęć i kategorii. A owa deegzystencjalizacja prowadzi do reifikacji tego, o czym się mówi. Innymi słowy, dotychczasowy język filozoficzny i religijny - przede wszystkim nowożytny i współczesny - deformuje rzeczywistość, wyzbywając się doświadczalnej podstawy myślenia. Stąd potrzeba ukucia nowego języka, który oddawałby strukturę doświadczenia i rzeczywistości. Z tego wyłania się uwaga metodologiczna: niezwykle trudno sparafrazować, przełożyć na bardziej zrozumiałe i ogólnie znane pojęcia nieraz hermetyczny język Voegelina, ponieważ każdorazowo może się to wiązać ze zmianą sensu, zmianą, która mogłaby z powrotem uwikłać pojęcia w sposób rozumienia charakterystyczny dla wspomnianej metafizyki obecności. Dlatego w artykule postawiłem na obecność cytatów, które choć czasem mogą wydawać się niejasne, to nie sugerują odczytania w ramach pojęć metafizyki obecności ${ }^{9}$. Czytelnikowi z racji relatywnej nieznajomości Voegelina w Polsce należy się pewna uwaga wstępna: najczęściej uważa się go za filozofa polityki oraz historii i w takim właśnie kontekście jego myśl jest przeważnie rozważana. To jednak specyficzna filozofia polityki i historii - jej jądrem jest bowiem filozofia świadomości, rdzeniem tej zaś - tak zwane wydarzenie teofaniczne, czyli doświadczenie boskości, według Voegelina konstytutywne zarówno dla filozofii, jak i religii. W pewnym sensie więc rdzeniem owej myśli jest filozofia świadomości i religii, a właściwie: świadomości boskości. Całość zaś tej myśli ma egzystencjalny charakter - zawsze bowiem chodzi Voegelinowi o sens i prawdę egzystencji.

Temat Chrystusa Voegelina często był poruszany przez innych badaczy ${ }^{10}$. Specyfiką tych prób była perspektywa porównawcza: to, co napisał Voegelin porównywano

o boskiej obecności, nadaje temu wyrażeniu sens zupełnie przeciwny (o boskiej obecności jako ruchu piszę w dalszej części artykułu).

${ }^{9}$ Podobną strategię przyjmuje Paul Caringella w swoim tekście Voegelin: Philosopher of Divine Presence (poświęconym późnej myśli Voegelina ze szczególnym uwzględnieniem jego teorii imaginacji i mitu). Zdaniem Caringelli każda parafraza myśli Voegelina wiąże się z jednej strony ze zniekształceniem tejże filozofii, z drugiej zaś - odbiera czytelnikowi możliwość obcowania ze specyficzną warstwą językową. Zob. P. Caringella, Voegelin: Philosopher of Divine Presence [w:] Eric Voegelin's Significance for the Modern Mind, E. Sandoz (red.), Baton Roque 1991, s. 188.

${ }^{10}$ Do najważniejszych artykułów poświęconych Voegelinowi i chrześcijaństwu oraz/lub Chrystusowi należą: B. Douglass, Okrojona Ewangelia..., s. 237-254; M. Henry, Eric Voegelin on Incarnate Christ, https://home.isi.org/eric-voegelin-incarnate-christ [dostęp: 12.01.2016]; G. Niemeyer, Christian Faith, and Religion, in Eric Voegelin's Work [w:] Within and Above Ourselves: Essays in Political Analysis, Wilmington 1996, s. 126-142; W.M. Thompson, Christ and Christianity in Israel and Revelation [w:] Voegelin's Israel and Revelation, W.M. Thompson, D.L. Morse (red.), Marquette 2000; s. 215-241. F.D. Wilhelmsen, Profesor Voegelin wobec tradycji chrześcijańskiej [w:] Problem ładu..., s. 255-272. $\mathrm{W}$ artykule jednak rozmyślnie nie podejmuję polemiki z rzeczonymi autorami: po pierwsze, $\mathrm{z}$ racji ich częstokroć teologicznego stanowiska, po drugie dlatego, iż - moim zdaniem - w niewystarczający sposób poruszają oni problem, jak w Chrystusie spotykają się kluczowe kategorie filozoficzne Voegelina (może 
- a to do symboli wiary ułożonych na pierwszych soborach, a to do dogmatyki protestanckiej. Innymi słowy, ich autorzy często atakowali Voegelina z pozycji religijnej, chrześcijańskiej, mając za wspólny punkt odniesienia credo nicejsko-konstantynopolitańskie i chalcedońskie wyznanie wiary. Oskarżano go o lekceważenie historyczności Jezusa ${ }^{11}$, deformację nowotestamentowej soteriologii i eschatologii ${ }^{12}$, platonizację chrześcijaństwa ${ }^{13}$ i przenikające wszystkie te „deformacje” odrzucenie realności Zmartwychwstania ${ }^{14}$.

\section{II}

Voegelin akceptuje stwierdzenie Husserla, że istotą świadomości jest intencjonalność: świadomość jest świadomością czegoś ${ }^{15}$. Inaczej niż Husserl, Voegelin woli mówić nie o świadomości przedmiotu, lecz o świadomości rzeczywistości (co ma duże konsekwencje). Jednocześnie bowiem świadomość jest wydarzeniem w tak zwanym procesie rzeczywistości. Co to znaczy? Człowiek wraz ze swoją świadomością nie tylko jest elementem rzeczywistości, jest także samoświadomy owej przynależności do rzeczywistości - wie, że wraz ze swoją świadomością przynależy on, jako część, do całości rzeczywistości współkonstytuowanej przez różnorakie (różne co do sposobu istnienia) momenty (w sensie Husserlowskiej niesamodzielnej części) owej rzeczywistości. Dystans, który w Husserlowskiej fenomenologii oddziela Ja i przeżycie od przedmiotu, Voegelin próbuje przebyć, uznając, że zarówno człowiek (świadomość intendująca przedmioty), jak i przedmioty są momentami tej samej, wszechogarniającej rzeczywistości. Filozof pisze nawet, że świadomość jest przedmiotem rzeczywistości rozumianej jako podmiot ${ }^{16}$.Świadomość funkcjonuje więc według filozofa $\mathrm{w}$ dwóch podstawowych modi: intencjonalności i wydarzenia rozświetlenia w rzeczywistości: „To więc jest podwójna struktura: mamy świadomość jako intencjonalność i jako wydarzenie rozświetlenia w rzeczywistości [tłum. - T.N.]"17. Stosowany przez Voegelina termin luminous ma wieloznaczny charakter i znaczy tyle co: rozświetlony, uczyniony widocznym, ukazanym - wydobyty z mroku, wreszcie - jak pisze Voegelin - inteligibilny, a więc rozumny, dający się

poza Michelem Henrym) - czyli omawiana przeze mnie dyferencjacja świadomości oraz dwa modi doświadczenia boskości. Poza tym wszyscy zgodnie wykazują, że Voegelin odróżnia Jezusa człowieka od Chrystusa jako pełni boskiej obecności, tym samym odrzucając dogmat. Żaden z autorów nie dotyka kluczowej problematyki niniejszego tekstu - tego, na co wskazuje Voegelinowska chrystologia, tj. ograniczenia możliwości jawienia się boskości.

${ }^{11}$ G. Niemeyer, op.cit.

${ }_{12}$ B. Douglass, op.cit., s. 244-245.

${ }_{13}$ F.D. Wilhelmsen, op.cit., s. 263-264.

${ }^{14}$ Ibidem, s. 259-260.

${ }^{15}$ E. Voegelin, Structures of Consciousness [w:] The Drama of Humanity and other Miscellaneous Papers 1939-1985, Columbia 2004, s. 353-354.

16 Ibidem, s. 355.

${ }^{17}$ „So this is double structure: We have consciousness, first, in this intentionality, and the as an event of luminosity in reality". Ibidem, s. 356. 
pojąć i wysłowić (nawet jeśli w terminach negatywnych). Właśnie w tym drugim modi bycia świadomości dystans dzielący Ja od przedmiotu zostaje przebyty poprzez doświadczenie, w którym poznający (doświadczający) i to, co poznawane, jawią się jako współprzynależne do tej samej rzeczywistości. Podkreślić ma to także stosowanie terminu wydarzenie (event) - świadomość i to, co ona przeżywa, mają charakter wydarzeniowy, są ulokowanym w czasie wydarzeniem, którego podmiotem jest raczej rzeczywistość. Albo inaczej rzecz ujmując: człowiek nie jest wyizolowanym bytem - a już na pewno nie transcendentalnym absolutem - bytuje jako moment i reprezentant rzeczywistości. Co więcej: człowiek to wyróżniony moment rzeczywistości - bowiem to w jego świadomości rzeczywistość zostaje doświadczona, pojęta i wyrażona (a więc rozświetlona) właśnie jako wszechogarniająca całość współkonstytuowana przez wielość momentów. Jest to możliwe dlatego, że człowiek i jego świadomość są częściami rzeczywistości - całość zostaje poznana właśnie jako całość przez część, która w trakcie doświadczenia rozpoznaje korelatywnie siebie jako część owej całości. O ile w modi intencjonalności świadomość poznaje przedmiot jako różny od siebie - choć konstytuowany jako przedmiot dla świadomości - a siebie jako izolowany podmiot (a w wersji idealistycznej jako absolut transcendentalny, który mógłby istnieć bez świata, lecz bez którego świat nie mógłby istnieć), o tyle w modi rozświetlenia człowiek doświadcza siebie samego i tego, co inne (nie zaś przedmiotu), jako ugruntowanych w tej samej podstawie, jako przynależnych do tego samego.

Postawmy jednak pytanie: czym jest rzeczywistość, jaka jest jej struktura, co to znaczy, że jest procesem? Dla zrozumienia tej problematyki kluczową kategorię stanowi tak zwana dyferencjacja świadomości. Voegelinowska koncepcja dyferencjacji świadomości wywodzi się z jego wczesnych koncepcji ontologicznych dotyczących tak zwanej wspólnoty istnienia, którą konstytuują człowiek, świat (kosmos), społeczeństwo i Bóg, tworzące razem całość rzeczywistości ${ }^{18}$. W tej wczesnej ontologii jądrem procesu dyferencjacji było odkrycie różnicy pomiędzy immanencją ziemskiego i wydanego czasowemu trwaniu kosmosu a transcendencją boskości, a także tego, że człowiek, egzystując, znajduje się w relacji do Boga, który jest podstawą istnienia oraz kierunkiem egzystencji. Na wczesnym poziomie tak zwanej zwartej świadomości (compact consciousness) boskość była doświadczana i symbolizowana (w postaci mnogości boskich istot) jako stopiona z materialnym kosmosem oraz sferą polityki. Dyferencjacja jest więc procesem doświadczenia i uświadomienia sobie wiecznej, duchowej i nieśmiertelnej natury boskości oraz odkryciem egzystencji człowieka jako Pomiędzy, metaxy (o czym będzie za chwilę). Dyferencja świadomości, jako wieloetapowy historyczny proces, ostatecznie prowadzi do wyłonienia się pewnej specyficznej formy świadomości - metaxy - w której dochodzi do samoobjawienia się boskości oraz rozświetlenia rzeczywistości w ich pełni, tj. w całości wzajemnych relacji i odniesień między częściami całości. Według austriackiego filozofa, dyferencjacja świadomości do pełnej postaci - a więc rozświetlenia metaxy świadomości jest dziełem przede wszystkim proroków Izraela, Platona i Arystotelesa oraz chrześcijaństwa. Każdy z tych „ruchów” odkrył i skupił swoją uwagę na pewnych regionach,

${ }^{18}$ E. Voegelin, Order and History. I: Israel and Revelation, Columbia 2001, s. 39. 
czy raczej momentach procesu rzeczywistości i świadomości metaxy. W tym sensie dyferencjacja świadomości jest długotrwałym i wieloetapowym procesem historycznym. W tym momencie znajdujemy się w centrum Voegelinowskich rozważań nad historią. Historia jest według Voegelina procesem, w trakcie którego człowiek doświadcza i artykułuje naturę swoją oraz rzeczywistości. Historia jako proces dyferencjacji świadomości jest więc niczym innym jak czasowym, stopniowym procesem samoobjawienia boskości i struktury rzeczywistości (wraz z człowiekiem) zgodnie z ich naturą. „Stąd jeśli historia jest procesem, w którym Wieczny Byt realizuje się w czasie, to filozofia jest historycznym wydarzeniem w tym określonym sensie, że Wieczny Byt staje się realny w czasie poprzez odpowiedź filozofa" ${ }^{19}$. Voegelin pisze dalej: „W pierwszej kolejności filozoficzne doświadczenie odsłania duszę jako locus napięć pomiędzy czasowym bytem doświadczającego człowieka i Wiecznego Bytu, którego realizacja jest doświadczana" ${ }^{20}$.W fillozoficznym doświadczeniu - ale także i religijnym (pneumatycznym) - dusza staje się sensorium struktury i napięć w rzeczywistości, przede wszystkim sensorium transcendencji. Voegelinowi chodzi o to, że proces dyferencjacji świadomości to taki, w którym wyłania się nowy wymiar świadomości - taki, w którym może dojść do rozświetlenia rzeczywistości. Nie można mówić o rzeczywistości poza świadomością, w której rzeczywistość się ukazuje i zostaje rozpoznana. To, co jest jest dla świadomości. W pewnym sensie istotą procesu rzeczywistości jest odkrycie przez człowieka specjalnego wymiaru świadomości, w którym rzeczywistość zostaje rozświetlona (ukazana/zrozumiana w sposób nieprzedmiotowy). Dlatego Voegelin traktuje proces dyferencjacji świadomości jako proces rzeczywistości.

Jońskie odkrycie konstytuuje pole noetycznej świadomości, w którym myśliciele postępują od zwartej prawdy procesu do zróżnicowanej prawdy odkrywającej świadomości. Co zaczyna się jako wgląd w tajemnicę i strukturę procesu, prowadzi do doświadczenia, które zostaje wyartykułowane we wglądzie, i dalej do uznania go za akt świadomości, poprzez który człowiek uczestniczy w procesie rzeczywistości. „Rzecz” , która zwie się człowiekiem, odkrywa siebie jako mającą świadomość; a w konsekwencji odkrywa świadomość człowieka jako region rzeczywistości, w którym proces rzeczywistości staje się rozświetlony dla siebie samego. Co więcej, jako że pole noetycznej świadomości odsłania w czasie przez kolejnych myślicieli, samo owo pole zostaje uznane za przynależące do struktury rzeczywistości. Proces nie jest nieświadomym następowaniem po sobie rzeczy; raczej jest on ustrukturyzowany w czasie przez progres noetycznej świadomości. Niemy proces, w którego sens można było wątpić, staje się procesem o wzrastającym stopniu artykulacji swego sensu; a tym, co zostaje odkryte jako jego sens, jest wyłonienie się w ramach procesu noetycznej świadomości ${ }^{21}$.

19 „Hence if history is the process in which Eternal being realizes in time, philosophy is a historical event in the precise sense that Eternal being becomes real in time through the response of the philosopher”. E. Voegelin, Eternal Being in Time [w:] Anamnesis, Columbia 1990, s. 313.

${ }^{20}$ „In the first place, the philosophical experience discloses the soul as the locus of the tensions between the temporal being of the experiencing man and Eternal being, whose realization is experienced". E. Voegelin, Eternal..., s. 321.

${ }^{21}$ „The Ionian discovery constitutes a field of noetic consciousness in which the thinkers advance from compact truth of the process to the differentiated truth of the discovering consciousness. What begins as an insight into mystery and structure of the process leads on to the experience that has become articulate in the insight, and further on to its recognition as an act of consciousness by which man 
Sensem procesu rzeczywistości jako procesu dyferencjacji świadomości jest wyłonienie się takiej świadomości, która stanie się zwrotnie świadomością owego procesu. Nie należy jednak zapominać, że tym, co ostatecznie jest nie tylko podstawą i celem rzeczywistości, lecz także tym, co motywuje wyłonienie się świadomości, jest boskość i jej samoobjawienie: „Historia nie jest strumieniem ludzi i ich działań w czasie, lecz procesem ludzkiej partycypacji w przepływie boskiej obecności o eschatologicznym kierunku"22. Wyłonienie się (samo)świadomości procesu wydarza się w odpowiedzi na boskie samoobjawienie. Dlatego rzeczywistość ma charakter procesu, w którym dyferencjacja świadomości (którą to Voegelin w pewnym sensie utożsamia z procesem rzeczywistości) jest procesem historycznym.

Na czym polega Voegelinowski egzystencjalizm? W toku historii, w wyniku teofanicznych wydarzeń, człowiek odkrywa, że sensem jego egzystencji jest ruch (movement) ku rozświetleniu rzeczywistości w świadomości²3. Ów ruch dokonuje się w Pomiędzy (In-Between) czy metaxy świadomości:

Egzystencja człowieka jest nie-faktem niepokojącego ruchu w Pomiędzy niewiedzy i wiedzy, tego, co czasowe i bezczasowe, niedoskonałości i doskonałości, nadziei i spełnienia, i ostatecznie życia i śmierci. $Z$ doświadczenia tego ruchu, z niepokoju dotyczącego utracenia prawidłowego kierunku w Pomiędzy ciemności i światła, z tego niepokoju wyłania się wgląd w sens życia. Lecz wyłania się tylko dlatego, że człowiek doświadcza swego bycia jako partycypacji w ruchu mającym kierunek, który można stracić lub odnaleźć. Gdyby ludzka egzystencja była faktem, nie ruchem, nie tylko byłaby pozbawiona sensu, ale i pytanie o sens bycia nie mogłoby zostać zadane ${ }^{24}$.

Fakty po prostu są i jako po prostu będące nie mają kierunku, ku któremu mogłyby zmierzać. Kierunek może mieć tylko to, co się porusza. Kierunkiem jest rozświetlenie rzeczywistości. Początkowo człowiek znajduje się w stanie niewiedzy co do sensu i podstawy swojej - z tego powodu człowiek doświadcza egzystencjalnego niepokoju (Voegelin pisze o anxiety lub existential unrest), w wyniku czego podejmuje poszukiwania owego sensu i podstawy. Ale warunkiem możliwości odczuwania niepokoju oraz poszukiwania sensu/podstawy (Voegelin niejako utożsamia sens

participates in the process of reality. The „thing” that is called man discovers itself as having consciousness; and as a consequence, it discovers man's consciousness as the area of reality in which process of reality becomes luminous to itself. Moreover, as the field of noetic consciousness unfolds in time through a succession of thinkers, the field itself comes to be recognized as belonging to the structure of reality. The process is not unconscious of „things”; rather it is structured in time by the progress of noetic consciousness. A mute process about whose meaning one could doubt becomes a process increasingly articulate about its meaning; and what is discovered as its meaning is the emergence of noetic consciousness in the process". E. Voegelin, Ecumenic..., s. 236.

${ }^{22}$ „History is not a stream of human beings and their action in time, but the process of man's participation in a flux of divine presence that has the eschatological direction”. E. Voegelin, Ecumenic..., s. 50.

${ }^{23}$ E. Voegelin, Ecumenic..., s. 246.

${ }^{24}$ „Existence is the nonfact of a disturbing movement in the In-Between of ignorance and knowledge, of time and timelessness, of imperfection and perfection, of hope and fulfillment, and ultimately of life and death. From the experience of this movement, from the anxiety of losing the right direction in this In-Between of darkness and light, arises the inquiry concerning the meaning of life. But it does arise only because life is experienced as man's participation in a movement with a direction to be found or missed. If man's existence were not a movement but a fact, it not only would have no meaning but the question of meaning could not even arise". E. Voegelin, The Gospel..., s. 176 
[kierunek] egzystencji z podstawą istnienia, a więc tym, z czego człowiek czerpie swoje istnienie) jest zawsze-już-obecne przyciąganie przez podstawę.

Bez kinesis, przyciągania przez podstawę, nie byłoby pożądania wiedzy; bez pożądania wiedzy nie byłoby zapytywania w stanie zmieszania; bez zapytania w stanie zmieszania nie byłoby świadomości ignorancji [niewiedzy - T.N.]. Nie byłoby niepokoju w stanie ignorancji, jeśli niepokój nie byłby ożywiany samoświadomością człowieka o istnieniu podstawy, którą on sam nie jest ${ }^{25}$.

Ów ruch, który jest istotą egzystencji, wydarza się w specyficznym „miejscu”. Voegelin pisze o egzystencjalnym napięciu (tension) między niewiedzą człowieka a kierunkiem egzystencji, którego poszukuje. Pierwotnie napięcie ludzkiej egzystencji konstytuowane jest przez ruch poszukiwania oraz bycia poruszonym (platońskie zetesis oraz kinesis). Napięcie jest więc dynamiczną relacją pomiędzy świadomością człowieka a podstawą istnienia/kierunkiem egzystencji, która przyciąga człowieka. Napięcie odsłania się jako napięcie między dwoma biegunami. Owe bieguny nie są jednak uprzednimi wobec relacji napięcia niezależnymi bytami, lecz wyłaniają się wraz z napięciem. Bieguny ukonstytuowane są w i przez napięcie ${ }^{26}$. Nie ma człowieka bez napięcia w jego egzystencji, a napięcie jest zawsze wobec podstawy/sensu istnienia (która jest dla Voegelina Bogiem). Człowiek egzystuje zawsze i każdorazowo - co znaczy, że znajduje się w relacji do Boga. Bóg może człowiekowi objawić się tylko w napięciu - ruchu i przeciwruchu. Ostatnim członem tej struktury jest zaś rozświetlenie (luminosity) owego napięcia - ruchu i przeciwruchu (movement and countermovement) biegunów, czy raczej partnerów owego ruchu, a więc ich uświadomienie. Metaxy (Voegelin zamiennie mówi o Pomiędzy świadomości lub o metaleptycznej świadomości) jest więc „regionem” świadomości, w którym konstytuują się napięcie wraz z biegunami, w których wszystkie te elementy zostają rozświetlone. Wreszcie człowiek, skoro nie jest „faktem”, lecz „ruchem”, otwiera się i musi pozostawać otwarty na ruch, poruszenie ze strony boskiej podstawy, oraz na konieczność odpowiedzi, przeciwruchu - stania się. Człowiek musi pozostawać otwarty na boskość i przygotowany na zmianę swego bycia oraz świadomości w odpowiedzi na wezwanie.

Metaxy nie może zostać zdefiniowana niczym obiekty świata zewnętrznego, nie jest przedmiotem. Jest wymiarem świadomości i tym samym rzeczywistości. W niej człowiek doświadcza boskości.

W filozoficznym doświadczeniu, ani wieczne istnienie nie staje się przedmiotem czasowym, ani doczesne istnienie nie zostaje przeniesione w wieczność. Pozostajemy w Pomiędzy, w czasowym przepływie doświadczenia, w którym obecna jest wieczność. Ten przepływ nie może zostać rozdzielony na przeszłość, teraźniejszość i przyszłość światowego trwania, ponieważ w każdym momencie przepływu jest $\mathrm{w}$ nim napięcie ku transcendentnemu, wiecznemu byciu. Terminem wyrażającym obecność wiecznego istnienia w czasowym przepływie jest przepływ obecności ${ }^{27}$.

25 ,Without the kinesis, the attraction from the ground, there is no desire to know; without the desire to know, no questioning in confusion; without the questioning in confusion, no knowledge of ignorance. There would be no anxiety in the stage of ignorance, unless anxiety were alive with man's knowledge of his existence from a ground that he is not himself'. E. Voegelin, Ecumenic..., s. 250.

26 E. Voegelin, Structures..., s. 163.

27 „In the philosophical experience, neither does eternal being become an object in time nor is temporal being transposed into eternity. We remain in the «In between», in temporal flow of experience in 
Transcendencja i immanencja nie są terminami wyrażającymi stałe położenie, a raczej kierunkami, w stronę których człowiek może się poruszać w Pomiędzy swojej świadomości. Człowiek doświadcza transcendentnego Boga nie jako przedmiotu poddanego czasowemu trwaniu, lecz jako nieprzewidywalnego i niemożliwego do kontrolowania przepływu boskiej obecności w świadomości. Bóg jest Bogiem transcendentnym zarówno w ontologicznym, jak i epistemologicznym sensie - wezwanie, poruszenie, objawienie się zależą od Boga. Jednakże to, co się wydarza w Pomiędzy świadomości: napięcie, doświadczenie, ekspresja owego doświadczenia - wszystko to jest $\mathrm{w}$ równym stopniu ludzkie, jak i boskie. W rzeczywistości metaxy nie ma niezależnych, odseparowanych bytów, a jedynie pozostające we wzajemnej relacji bieguny.

\section{III}

Zanim przejdę do właściwych analiz poświęconych chrystologii filozoficznej, zarysuję jeszcze jeden horyzont teoretyczny, w ramach którego Voegelin rozpatruje fenomeny religijne. W eseju The Beginning and the Beyond czytamy: „Boska rzeczywistość jest objawiana człowiekowi $\mathrm{w}$ dwóch fundamentalnych modi doświadczenia: $\mathrm{w}$ doświadczeniu boskiej kreatywności w kosmosie oraz w doświadczeniu porządkującej, boskiej obecności w duszy" ${ }^{28}$. W pierwszym modi boskość jest doświadczana w sposób pośredni - jako siła udzielająca wszystkim bytom istnienia i porządku, w ramach którego istnieją; $\mathrm{w}$ drugim przypadku mamy do czynienia $\mathrm{z}$ bezpośrednim doświadczeniem, tj. teofanicznym wydarzeniem boskiego ruchu w metaxy świadomości. Drugi ze sposobów doświadczania wyraża się w języku poszukiwania, zapytywania, niepokoju, konwersji, pochwycenia, porwania itp. Symboliczną ekspresją tego pierwszego jest natomiast mit, rozumiany przez austriackiego filozofa jako alethinos logos - w bezpośrednim doświadczeniu to, o czym się mówi, jest bezpośrednio „dane” w metaxy świadomości, daje się wskazać; podczas gdy mit dotyczy - przynajmniej na etapie The Ecumenic Age - tego, czego nie da się wskazać w bezpośrednim doświadczeniu, mit jest więc prawdopodobną opowieścią na temat początku i końca rzeczywistości z boskiej podstawy. Z tej przyczyny mit jest tylko prawdopodobną opowieścią - tego, o czym mówi, nie możemy bezpośrednio doświadczyć w metalaleptycznej świadomości, ponieważ dotyczy genezy i końca rzeczywistości, której świadomość sama jest momentem. Oznacza to także, po pierwsze, iż mitem jest każda opowieść o początku i końcu świata, oraz po drugie, że mit nie jest jakąś przestarzałą formą wiedzy, lecz niezbywalnym składnikiem ludzkiej egzystencji. Nadto trzeba jeszcze

which eternity is present. This flow cannot be dissected into past, present, and future of the world's time, for at every point of the flow there is tension toward the transcending eternal being. This characteristic of the presence of eternal being. In temporal flow may be represented by the term flowing presence". E. Voegelin, Eternal..., s. 133.

${ }^{28}$ E. Voegelin, The Beginning and the Beyond: A Meditation on Truth [w:] What is History? And Other Late Unpublished Writings, Baton Rouge 1990, s. 173. „Divine reality is being revealed to man in two fundamental modes of experience: in the experience of divine creativity in the cosmos; and in the experience of divine ordering presence in the soul". 
powiedzieć o wzajemnym stosunku owych dwóch typów doświadczenia i symbolizacji. Teofaniczne wydarzenie jest „dyferencjacją egzystencjalnej prawdy” - w nim człowiek zyskuje świadomość istnienia transcendentnej boskiej rzeczywistości oraz tego, że on sam - człowiek - istnieje w odniesieniu do owej rzeczywistości. Jednakże owo doświadczenie nic nie mówi o kosmosie - wciąż pozostaje bowiem problem doświadczanej pośrednio przez człowieka boskości w kosmosie. Człowiek identyfikuje te dwie doświadczane przez niego boskości - transcendentny Bóg teofanicznego wydarzenia jest tym samym Bogiem, który powołuje do istnienia i utrzymuje w istnieniu świat.

Kiedy świadomość zostaje rozświetlona przez hierofaniczne wydarzenie, jego symbolizacja rzeczywistości musi pogodzić zarówno Ponad, jak i Początek. Bosko-kosmiczny początek wymaga jednakże do ekspresji opowieści Genesis, kosmogonicznej opowieści. Musiałem uznać, że mit kosmologiczny znika nie bardziej niż kosmos ${ }^{29}$.

W poszukiwaniu odpowiedzi na pytanie, jak ma wyglądać relacja między dwoma typami doświadczenia i symbolizacji, Voegelin odwołuje się właśnie do platońskiej koncepcji alethinos logos: opowieść mityczna może rościć sobie pretensję do prawdy tylko wtedy, gdy ,[...] pasuje do poznawczej świadomości porządku rzeczywistości wyłonionego w duszy człowieka poprzez erotyczne napięcie ku boskiemu Ponad"30. Innymi słowy, mit można uznać za prawdziwy wtedy, gdy to, o czym mówi, pozostaje w zgodzie z porządkiem odsłoniętym w metaxy świadomości. Miarą prawdziwości mitu jest porządek duszy wyłoniony w metaxy świadomości przez ruch boskiej obecności i ludzkie poszukiwanie podstawy istnienia.

Przechodząc do problemu Chrystusa w filozofii Voegelina, proponuję zacząc od historii, fenomenu, który był dla filozofa przedmiotem szczególnego zainteresowania. Doświadczenia i ich symbolizacje nie są bowiem wyizolowanymi, samodzielnymi fenomenami, lecz wydarzeniami w procesie rzeczywistości - a każde wydarzenie odniesione jest do przeszłości i przyszłości. Rozważając więc wydarzenie teofaniczne, nie można abstrahować od kontekstu historycznego - koniecznym warunkiem rozumienia jest więc uwzględnienie procesu dyferencjacji, co znaczy, że każde wydarzenie należy odnieść do poprzedzających je bardziej zwartych doświadczeń i symbolizacji. Zdaniem Voegelina, jedną z fundamentalnych różnic pomiędzy noetycznym doświadczeniem filozofii a pneumatycznym doświadczeniem religii jest właśnie stosunek Ponad/Beyond i Początku/Beginning - helleńscy filozofowie kładli

${ }^{29}$, ,[...] when consciousness has become luminous through the hierophanic events, its symbolization of the reality must now accomodate both the Beyond and the Beginning. The divine-cosmic beginning, however, requires for its expression a story of Genesis, a cosmogonic tale. No more than the cosmos, I had to conclude therefore, will the cosmogonic myth dissapear". E. Voegelin, Ecumenic..., s. 54. Na marginesie pragnę zauważyć, że Voegelin - ja również idę za jego przykładem - zamiennie mówi o Ponad/Beyond i boskim (divine) Ponad/Beyond. Nie jest to przeoczenie, ponieważ jedyna transcendencja, jedyne Ponad, to boska transcendencja, boskie Ponad. Poza Bogiem nie ma żadnej transcendencji - według Voegelina. Ludzka zdolność transcendowania za warunek możliwości ma właśnie boską transcendencję - człowiek transcenduje o tyle, o ile transcenduje ku boskości. W myśli Voegelina mówienie o transcendencji jako czymś niezwiązanym z boskością jest pozbawione sensu.

${ }^{30}$, ,...] fits the cognitive consciousness of order created in the soul of man by the erotic tension toward the divine Beyond". E. Voegelin, Ecumenic..., s. 56. 
akcent na wgląd w strukturę rzeczywistości, w porządek rzeczywistości. Dla izraelickiego doświadczenia paradygmatyczne było samoobjawienie Boga w krzewie gorejącym (Wj 3,14), w którym Bóg objawia się jako absolutne istnienie - to Bóg jest tym, który istnieje przed światem i który mocą swego słowa powołuje go do istnienia.

W Ewangelii Jana Chrystus przemawia do faryzeuszy: „Powiedziałem wam, że pomrzecie w grzechach swoich. Tak, jeżeli nie uwierzycie, że JA JESTEM, pomrzecie w grzechach swoich" (J 8, 24). Według filozofa Bóg, który przemawiał w krzewie gorejącym do Mojżesza, ujawniając swoje imię JA JESTEM, w ewangelii przemawia ustami człowieka. Wydarzenie opisane w Księdze Wyjścia, pomimo że dotyczy transcendentnego Boga Ponad, wciąż wykazuje wiele cech kosmologicznych: Bóg objawia w krzewie, roślinie, części materialnego kosmosu; objawia się tylko Mojżeszowi, wybranemu; a celem owego objawienia jest ukonstytuowanie politycznej wspólnoty Izraela $-\mathrm{z}$ jednej strony dochodzi do zerwania $\mathrm{z}$ koncepcją Boga jako elementu kosmosu, $\mathrm{z}$ drugiej jednak ludzkim biegunem nie jest tu indywidualna, konkretna dusza (i świadomość), lecz wspólnota. Natomiast „Ja jestem” w Jezusie ,[...] objawia siebie jako żywa obecność Słowa w Człowieku”, którego celem nie jest ukonstytuowanie historycznej wspólnoty (zdaniem Voegelina ukonstytuowanie się Kościoła jest raczej wynikiem objawienia niż jego bezpośrednim celem), lecz „rozwianie mroku i absurdu egzystencji w rozświetloną świadomość partycypacji w boskim Słowie"31. Obecność boskości w Jezusie skutkuje samoświadomością partycypacji w boskim Słowie. Ale owa obecność boskiego Słowa jest obecnością w Jezusie, człowieku. Jezus jest, zdaniem Voegelina, reprezentantem człowieka w ogóle - tym samym obecność boskiego Słowa w Jezusie oznacza możliwość obecności Słowa w każdym, i to w każdym indywidualnie. Voegelin przytacza epizod z Ewangelii Mateusza (16, 13-20):

Gdy Jezus przyszedł w okolice Cezarei Filipowej, pytał swoich uczniów: „Za kogo ludzie uważają Syna Człowieczego?” A oni odpowiedzieli: „Jedni za Jana Chrzciciela, inni za Eliasza, jeszcze inni za Jeremiasza albo za jednego z proroków”. Jezus zapytał ich: „A wy za kogo mnie uważacie?” Odpowiedział Szymon Piotr: „Ty jesteś Mesjasz, Syn Boga żywego”.

Według autora Order and History Piotr rozpoznaje obecność boskości w Jezusie nie dlatego, że otrzymał informację o tym od Jezusa albo kogoś innego, lecz dlatego że boska obecność w nim samym (Piotrze) pozwoliła mu (Voegelin pisze o poruszeniu) dostrzec pełnię boskiej obecności - „Boga żywego” - w Jezusie ${ }^{32}$. Człowiek ma możliwość rozpoznania boskości w Jezusie tylko o tyle, o ile jest ona już obecna w nim samym. „Bóg żywy”, boski biegun metaxy, jest w każdym człowieku - może poruszyć duszę każdego. Boskie Synostwo nie jest więc jakąś informacją przekazaną przez Jezusa uczniom - rozpoznanie go stanowi odpowiedź ludzkiego bieguna metaxy na pełnię obecności (fullpresence) Boga w Jezusie. Trzeba już egzystować

${ }^{31}$ „The I am in Jesus, on the other hand, reveals itself as a living presence of the Word in man; it does not intend to establish a people in history but will, for every man who responds to its appeal, dissolve the darkness and absurdity of existence into luminous consciousness of participating in the divine word". E. Voegelin, Ecumenic..., s. 59.

${ }^{32}$ E. Voegelin, Wisdom and Magic of the Extreme: A Meditation [w:] Published Essays 1966-1985, Baton Rogue 1990, s. 368. 
w otwartości na boskość, w metaxy - a więc trzeba być już uprzednio poruszonym przez Boga - aby rozpoznać pełnię obecności Boga w Jezusie. Zdaniem Voegelina, taka świadomość Jezusa i apostołów przenika Ewangelię. To właśnie dzięki Jezusowi prawdą egzystencji każdego człowieka, jednostki, stały się: napięcie ku boskiej podstawie istnienia i konieczność odpowiedzi na ruch boskiej obecności.

Voegelin rozważa jednak postać Chrystusa w kontekście procesu dyferencjacji nie tylko odnośnie do pneumatycznego doświadczenia Izraela - pod rozwagę bierze także większą adekwatność względem noetycznej świadomości.

W ruchu klasycznej fillozofii, jak pokazałem, noetyczna analiza świadomości posunęła się tak daleko jak w ruchu ewangelii, a w niektórych kwestiach pozostaje ona nadrzędna wobec czegokolwiek, co możemy znaleźć w ewangelii, jednakże decydujący krok w kierunku uczynienia ludzkiego napięcia ku Nieznanemu Bogu prawdą, do której musi się dopasować każda prawda rzeczywistości, nie został przez nią [klasyczną filozofię -T.N.] podjęty ${ }^{33}$.

Platon, według Voegelina, odkrył i wypowiedział transcendentnego Boga, jednakże w Fajdrosie jego jednorodzonym (monogenes) jest nie człowiek, a kosmos. Podczas świąt tylko wewnątrzkosmiczni bogowie olimpijscy mogą dotrzeć do szczytu niebios, tam na granicy mogą kontemplować to, co Ponad niebem. Żaden z ludzi nie będzie w stanie osiągnąć tego najwyższego stanu kontemplacji, żaden poeta nigdy nie będzie w stanie wysłowić hyperouranion. W Platońskim micie to bogowie egzystują w napięciu ku temu, co ponad niebem, przekazując wiedzę o tym ludziom. Zdaniem autora Order and History, greckimi odpowiednikami Syna Bożego są właśnie olimpijscy bogowie, którzy poszukują i znają transcendentnego Boga ${ }^{34}$. W Ewangelii i chrześcijaństwie to Jezus Chrystus jest Synem Bożym, obrazem (eikon) transcendentnego Boga. Miejsce bogów zajmuje człowiek - miejscem, w którym objawiony zostaje nieznany, ponadkosmiczny Bóg, staje się dusza człowieka i metaxy świadomości. „Siłą ewangelii jest jej koncentracja na tej jednej kwestii, która jest kluczowa: prawda rzeczywistości koncentruje się nie w kosmosie, nie w naturze czy społeczeństwie, ale w obecności Nieznanego Boga w ludzkiej egzystencji [...]"35.

Owo „Ja jestem”, wypowiedziane przez Jezusa, według Voegelina zawiera oprócz afirmacji absolutnego istnienia Boga (Mojżesz) oraz stwierdzenia przepływu boskiej obecności w każdym człowieku (Jezus w Ewangelii Jana), jeszcze trzecie znaczenie: eschatologiczne. Kwestia eschatologii ewokuje znów stosunek pomiędzy dwoma modi doświadczania i symbolizowania boskości - Ponad/Beyond i Początek/Beginning. Napięcie między biegunami metaxy jest konstytuowane zarówno przez boski ruch, jak i przez ludzką odpowiedź (przeciwruch). Nie ma świadomości, doświadczenia boskości bez przeciwruchu człowieka wychodzącego ku Bogu. Ale prawdziwy

${ }^{33}$ „In the movement of classic philosophy, as I have show, the noetic analysis of the metaxy has gone as far as in the gospel movement, and in some points is superior to anything we find in the gospel movement, but the decisive step of making the experience of man's tension toward the Unknown God the truth to which all truth of reality must conform was never taken”. E. Voegelin, The Gospel..., s. 208.

${ }^{34}$ Ibidem, s. 209.

${ }^{35}$ „The strength of the gospel is its concentration on the one point that is all-important: that the truth of reality has its center not in the cosmos at large, not in nature or society or imperial rulership, but in the presence of the Unknown God in man's existence [...]". E. Voegelin, The Gospel..., s. 210. 
sens przeciwruchu zostaje rozświetlony dopiero na wyższym poziomie dyferencjacji świadomości - gdy jest doświadczany i symbolizowany jako transcendowanie ku transcendencji Boga ${ }^{36}$. Wtedy ruch w Pomiędzy świadomości staje się ,unieśmiertelniającym przeciwruchem ku boskiemu Ponad"37.

W epifanii Chrystusa, istniejąca w historii ludzkość stała się samoświadoma sensu jako procesu transformacji. W osobie Jezusa partycypacja jego człowieczeństwa w boskim Słowie osiągnęła stopień jego absorpcji w Słowo"38.

W Jezusie Chrystusie ludzkość stała się więc świadoma, że historia nie jest ani nieskończonym i bezsensownym procesem następujących po sobie pokoleń; ani procesem, którego cel tkwi w immanencji wszechświata, lecz procesem, którego cel znajduje się w Ponad (Beyond), czyli transcendencji poza historią i kosmosem. Ów proces transformacji czy transfiguracji rzeczywistości pozostaje jednak tajemnicą, ponieważ mimo że ów proces zostaje uświadomiony, to jego konkretny charakter mieści się w przyszłości, a więc nie jest dany w doświadczeniu bezpośrednio, tak jak ruch boskiej obecności ku duszy i odpowiedź, przeciwruch człowieka. Eschatologia dotyczy końca rzeczywistości, który znajduje się poza „teraźniejszością metaxy”, domaga się więc swojej ekspresji języka mitu i poszanowania swojej niepoznawalności. Jednakże częstokroć pneumatyczne doświadczenie wiąże się z wiarą w natychmiastowe zbawienie, w którego wizji kosmos może przestać jawić się jako ogarniający człowieka moment rzeczywistości - jako struktura rzeczywistości egzystencji człowieka - i stać się demonicznym więźniem dla duszy, z którego potrzeba się wyzwolić. Ten problem Voegelin analizuje na przykładzie św. Pawła. Zdaniem Voegelina, te wątpliwości nie są nieuzasadnione - moc, z jaką objawia się Bóg Ponad, obietnica transfiguracji, mogą ewokować pytanie o sens istnienia kosmosu - po co powstał kosmos, skoro człowiek musi zostać od/z niego zbawiony, czy twórcą świata faktycznie jest dobry Bóg Ponad ${ }^{39}$ ?

Aby wyjaśnić sens eschatologicznego „Ja jestem”, Voegelin zwrócił się ku hermeneutyce pism związanych z osobą św. Pawła. „Wizja zmartwychwstałego przekonała świętego Pawła, że człowiek jest przeznaczony do wzrastania ku nieśmiertelności,

${ }^{36}$ Chociaż językowo adekwatnie byłoby mówić o transcendowaniu ku transcendentnemu Bogu, to jednak preferuję mówienie o transcendencji Boga. Transcendencja według Voegelina nie jest bowiem jakimś miejscem, lecz raczej kierunkiem, w którym może się poruszać człowiek w obrębie metaxy egzystencji.

${ }^{37},[\ldots]$ immortalizing countermovement toward the Beyond”. E. Voegelin, Ecumenic..., s. 62.

38 Ibidem, s. 62.

${ }^{39}$ Jednak, zdaniem Voegelina, chociaż ostateczny sens kosmosu rozpiętego pomiędzy boskim Początkiem i boskim Końcem pozostaje tajemnicą, to należy zaakceptować faktyczność takiego stanu rzeczy. Człowiek, o ile jest człowiekiem, egzystuje w kosmosie i nic na to nie może poradzić. Każda forma odrzucenia kosmosu pozostaje dla Voegelina ostatecznie formą gnozy, której możliwość zasadza się na zamknięciu na boską rzeczywistość. SamVoegelin pisze tutaj o tym, że aby nie popaść w gnostycyzm, należy: „There is no alternative to eschatological extravaganza but to accept the mystery of the cosmos. Man's existence is participation in the reality. It imposes the duty of noetically exploring the structure of reality as far as it is inteligibille and spiritually coping with the insight into its movement from the divine Beginning to the divine Beyond of its structure". E. Voegelin, Ecumenic..., s. 74. 
jeśli otworzy się na boską pneumę, jak uczynił to Jezus" ${ }^{\text {40 }}$. Odpowiedzią - czyli przeciwruchem człowieka w wydarzeniu teofanicznym - Pawła na wizję Chrystusa w drodze do Damaszku było obwołanie Jezusa Synem Bożym (Dz 9, 20). Voegelin za Pawłem rozszerza ten tytuł na wszystkich ludzi: „Albowiem wszyscy ci, których prowadzi Duch Boży, są synami Bożymi” (Rz 8, 14). Owa obecność przepływu boskiej obecności w Jezusie i każdym człowieku wiąże się z wiarą: „A jeżeli mieszka w was Duch Tego, który Jezusa wskrzesił z martwych, to ten, co wskrzesił Chrystusa «Jezusa» z martwych, przywróci do życia wasze śmiertelne ciała mocą mieszkającego w was swego Ducha" (Rz 8, 11). W końcu Voegelin konkluduje, że wiara w Chrystusa jest przeciwruchem ludzkiego bieguna metaxy na przepływ boskiej obecności - w Jezusie i każdym człowieku z osobna. „Kiedy wizjoner «widzi», jest świadom prawdy unieśmiertelniającej transfiguracji poprzez bosko-ludzki ruch w Pomiędzy, wtedy dokonuje się tranfiguracja" ${ }^{41}$. Kiedy w wyniku bosko-ludzkiego (divine-human) ruchu w świadomości Pomiędzy rozświetleniu ulega ta dynamiczna struktura (czyli kiedy rodzi się świadomość owej struktury), rozpoczyna się proces transfiguracji. Widzialność prawdy wydarzenia teofanicznego sama jest rozpoczęciem procesu „unieśmiertelniania”. Innymi słowy, według Voegelina, objawienie samo w sobie jest wydarzeniem transfiguracji, tj. rozpoczęciem procesu tranfiguracji. W zmartwychwstaniu Jezusa zostaje ukazana prawda eschatologii - proces zbawienia dokonuje się dzięki ruchowi epifanii i przyciągania przez boskość. Ale owa prawda eschatologii jest prawdą egzystencji w ogóle: być - to być w otwartości na boski ruch, który unieśmiertelnia. Jednocześnie, według filozofa, Jezus wskazuje, że ów ruch ku transfiguracji znajdzie swe spełnienie w przyszłości, że domaga się końca, absolutnego końca poza rzeczywistością procesu:

Teofaniczne wydarzenie konstytuuje sens w historii; objawia ono, że rzeczywistość zmierza ku stanowi nie niepokojonemu przez moce nieporządku; wyobraźnia, podążając za ukierunkowanym ruchem, wyrazi cel [owego ruchu -T.N.] przez takie symbole przemienionej/transfigurowanej rzeczywistości, jak „Nowe Niebiosa i Nowa Ziemia”42.

Według Voegelina, Paweł był tego świadom. Tym samym proces rzeczywistości zmierza do swojego końca - transfiguracji - który jest poza nim samym. Jak już wspominałem, ów ruch ma charakter tajemnicy - człowiek nie wie i nie może wiedzieć, dlaczego rzeczywistość znajduje się w takim stanie, że transfiguracja jest konieczna, dlaczego owo wydarzenie jeszcze się nie wydarzyło, nie może także przewidzieć daty przyszłego wydarzenia. Jednakże owa świadomość tajemnicy może zostać przesłonięta przez apokaliptyczne i gnostyczne oczekiwanie natychmiastowego

${ }^{40}$ E. Voegelin, Wizja Zmartwychwstatego u świętego Pawta, „Teologia Polityczna” 2012, nr 6, thum. M.J. Czarnecki, s. 204.

${ }^{41},[\ldots]$ and the event is epochal because the visionary is conscious that the truth of immortalizing transfiguration through the divine-human movements in metaxy, when «seen», transfigures". E. Voegelin, Wisdom..., s. 370.

42 „The theophanic event constitutes meaning in history; it reveals reality as moving toward a state undisturbed by forces of disorder; and imagination, following the directional movement, will express its goals by such symbols of transfigured reality as «a New Haven and a New earth»". E. Voegelin, Ecumenic..., s. 303. 
końca kosmosu. Do wyłonienia się oczekiwań apokaliptycznych dochodzi, zdaniem Voegelina, za każdym razem, kiedy napięcie pomiędzy objawionym przez Boga przyszłym porządkiem a aktualnie doświadczanym nieporządkiem staje się zbyt duże - traumatyczne doświadczenia (traumatic experience) mogą więc wywołać tak zwane metastatyczne - czyli apokaliptyczne i gnostyczne - oczekiwania. Paradoks tajemnicy - świadomość, że transfiguracja jeszcze się nie wydarzyła, więc jest „daleko", ale może się wydarzyć w każdej chwili - może przeistoczyć się z oczekiwania w pewność co do czasu nadejścia transfiguracji.

Voegelin doszukuje się tego napięcia u Pawła (Rz 8, 18-25):

Sądzę bowiem, że cierpień teraźniejszych nie można stawiać na równi z chwałą, która ma się $\mathrm{w}$ nas objawić. Bo stworzenie $\mathrm{z}$ upragnieniem oczekuje objawienia się synów Bożych. Stworzenie bowiem zostało poddane marności - nie z własnej chęci, ale ze względu na Tego, który je poddał - w nadziei, że również i ono zostanie wyzwolone z niewoli zepsucia, by uczestniczyć w wolności i chwale dzieci Bożych. Wiemy przecież, że całe stworzenie aż dotąd jęczy i wzdycha w bólach rodzenia. Lecz nie tylko ono, ale i my sami, którzy już posiadamy pierwsze dary Ducha, i my również całą istotą wzdychamy, oczekując ,przybrania za synów"- odkupienia naszego ciała. W nadziei bowiem już jesteśmy zbawieni. Nadzieja zaś, której [spełnienie już się] ogląda, nie jest nadzieją, bo jak można się jeszcze spodziewać tego, co się już ogląda? Jeżeli jednak, nie oglądając, spodziewamy się czegoś, to z wytrwałością tego oczekujemy.

Zdaniem Voegelina, Paweł ujmuje przemienioną rzeczywistość jako pozbawioną przemijania (Phtora). Austracko-amerykański filozof wskazuje, że różnica pomiędzy noetyczną filozofią Platona i Arystotelesa a pneumatycznym doświadczeniem Pawła polega na przesunięciu akcentu $\mathrm{z}$ kontemplowania (i afirmacji) porządku wcielonego w kosmosie na zbawienie, $\mathrm{z}$ doświadczenia ruchu rzeczywistości na jego zwieńczenie w boskim Ponad, na jego transfigurację (Kor 15, 51-52):

Oto ogłaszam wam tajemnicę: nie wszyscy pomrzemy, lecz wszyscy będziemy odmienieni. W jednym momencie, w mgnieniu oka, na dźwięk ostatniej trąby - zabrzmi bowiem trąba umarli powstaną nienaruszeni, a my będziemy odmienieni. Trzeba, ażeby to, co zniszczalne, przyodziało się w niezniszczalność, a to, co śmiertelne, przyodziało się w nieśmiertelność.

I właśnie w tym oczekiwaniu tkwi możliwość „wykolejenia” (dereilment) w postaci pewności rychłego przemienienia, zbawienia jednych i potępienia drugich itp. Pytaniem jeszcze pozostaje, skąd Paweł wiedział o ruchu rzeczywistości, o tranfiguracji - uważny czytelnik może oczekiwać, że wiedza Pawła wynika z wydarzenia teofanicznego, i będzie miał rację. Zdaniem Voegelina, za teologią Pawłową stoi bowiem Wizja Zmartwychwstałego (jak już wspomniałem ludzkim przeciwruchem na wizję jest wiara w Chrystusa, czyli partycypacja w tej samej boskiej neumie, która była aktywna [active] w Jezusie). Bez Bożej obecności, boskiego ruchu w Jezusie niemożliwa byłaby wiara w Chrystusa i w konsekwencji - teologia Pawła. Wiara w Chrystusa oznacza partycypację w tej samej boskości, która ukazała się w Jezusie i wizji Zmartwychwstałego. W wypadku Pawła owa wiara rodzi się z doświadczenia wizji. Zdaniem Voegelina, i wiara, i wizja przynależą do porządku metaleptycznej świadomości, świadomości Pomiędzy, a nie do dogmatu i doktryny. 
Kiedy pisze on, że wiara w Chrystusa jest partycypacją w boskiej pneumie w odpowiedzi na ruch boskości ujawnionej pierwotnie w osobie Jezusa, to widać tym samym, że jego Jezus Chrystus nie jest drugą osobą Trójcy Świętej współistotną Ojcu, lecz człowiekiem. Dla filozofa istnieje różnica pomiędzy Jezusem a Chrystusem: „[...] Chrystusa należy zdefiniować jako [...] maksymalną obecność - the pleroma of parousia - boskości w człowieku"43. Chrystus jest przepływem boskiej obecności w metaxy świadomości w stopniu maksymalnym- stopniu, w którym nie stał się udziałem żadnego innego człowieka. To boskie Słowo objawia transfigurację jako prawdę egzystencji człowieka. Jezus jest zaś człowiekiem, w którego świadomości w pełni objawił się Chrystus. „W metaleptycznym kontekście Wcielenie jest rzeczywistością boskiej obecności w Jezusie, tak jak doświadczali jej ludzie będący jego uczniami i jak ją wyrazili w symbolu «Syna Bożego» i jego ekwiwalentach[...]”44. Zdaniem Voegelina, symbol Syna Bożego oznacza właśnie ową obecność boskiego ruchu w metaxy. Nic więcej. Autor Order and History odrzuca mówienie i myślenie o Chrystusie w terminach unii, natury, substancji czy osoby, ponieważ uznaje je za przejaw hipostazowania, czyli deformowania procesu rzeczywistości i świadomości Pomiędzy. Hipostazowanie bowiem, po pierwsze, zmienia charakter procesu rzeczywistości i boskiej obecności jako przepływu, czyniąc je faktami. Fakt bowiem jest czymś skończonym - czymś, co już przybyło do bycia, a jego sposobem bycia jest trwanie ${ }^{45}$. Proces się dzieje, rzeczy przybywają do istnienia i odchodzą, boska obecność także ma charakter płynny, podobnie jak egzystencja w metaxy. Po drugie, dla Voegelina dogmat chrześcijański wypacza rzeczywistość egzystencji jako napięcia między dwoma biegunami, w którym nie ma samodzielnych bytów, lecz są właśnie „bieguny” odniesione do siebie zawsze i każdorazowo, a wiara w dogmat ${ }^{46}$, to wiara podmiotu w przedmiot, który jest czymś innym, różnym od podmiotu, a relacja między nimi jest wtórna wobec ich bytowej samodzielności. Jak wiemy, dla filozofa metaxy jest zaś wspólnotą. Co więcej, egzystencja w metaxy jest zawsze egzystencją konkretnego człowieka, uwarunkowanego historycznie, kulturowo itp. Taka też jest relacja między człowiekiem a Bogiem w metaxy: niepowtarzalna, jednostkowa. Dogmat zaś zmienia wydarzenie teofaniczne w coś niezmiennego, w co należy uwierzyć niezależnie od tego, kim i kiedy się jest. Dla Voegelina dogmatyzacja wydarzenia teofanicznego stanowi jego deegzystencjalnizację. Wydarzeniowy charakter symboli religijnych i filozoficznych zmienia się w uprzedmiotowiający w swej istocie język dogmatu - zestawu twierdzeń do przyjęcia.

${ }^{43}$ E. Voegelin, Structures..., s. 372.

${ }^{44}$ E. Voegelin, Wizja, s. 205.

${ }^{45}$ W. Stróżewski, Ontologia, Kraków 2004, s. 183.

${ }^{46}$ Co nie zmienia faktu, że Voegelin w pewnym momencie - i, o ile mi wiadomo, tylko raz - uznał, iż jego koncepcja pleromatycznej obecności Boga w metaxy w osobie Jezusa jest prawidłową egzegezą definicji wykutej na soborze chalcedońskim. Krytycznie ową pretensję Voegelina traktuje Michael Henry. Według niego, Chrystus Voegelina nie jest w pełni człowiekiem, ani Bogiem - raczej nie jest żadnym $\mathrm{z}$ nich w pełni. Zob. M. Henry, Eric Voegelin on Incarnate Christ... 
Pozostaje jeszcze pytanie, czy rozumienie Chrystusa Voegelina kończy się na takiej interpretacji? Można bowiem zadać pytanie, czy taka koncepcja chrystologiczna i związane z nią odrzucenie tradycyjnego ujmowania Jezusa Chrystusa nie wskazują na jeszcze coś innego? Należy jednak zwrócić uwagę, że podejmowana próba nie jest motywowana chęcią obrony tradycyjnego stanowiska, ale jedynie refleksji nad tak ostrym i kategorycznym odrzuceniem dogmatu. Dlaczego filozof wyczulony na historyczny wymiar hermeneutyki nie podjął próby interpretacji twórczości ojców Kościoła, której skutkiem jest symbol nicejsko-konstantynopolski? Dlaczego nie zapytać więc o doświadczenie, świadomość, której ekspresją był dogmat? Dlaczego filozof nie zbadał Wcielenia jako ostatecznej możliwości kenozy?

Filozof pisze:

Przez wcielenie rozumie się (według drugiego rozdziału Listu do Koryntian) obecność theotes, boskiej rzeczywistości. Jeśli przeczytać tylko Kolosan i [żadnego innego tekstu], to można wywnioskować, że Chrystusa należy zdefiniować jako maksymalną obecność - pleroma of parousia - boskości w człowieku. [...] Theotes nie oznacza osobowego Boga, ale - można powiedzieć, że w Platońskim sensie - obecność boskiej rzeczywistości doświadczanej w rzeczywistości przez ludzi, którzy stali wokół i słuchali mów Chrystusa ${ }^{47}$.

W polskim przekładzie fragment ten wygląda tak: „W Nim bowiem mieszka cała Pełnia: Bóstwo na sposób ciała" $(\mathrm{Kol} 2,9)^{48}$. Odnośnie zaś do terminu theotes Voegelin pisze:

Nad różnorodnymi tłumaczeniami jako tego, co boskie, boskości czy bóstwa, z których wszystkie implikują osobowego Boga, przedkładam boską rzeczywistość, ponieważ najlepiej oddaje intencję autora wyrażenia nieosobowej rzeczywistości, która pozwala partycypować w swojej pełni, w różnym stopniu pozostając Bogiem Ponad Pomiędzy egzystencji ${ }^{49}$.

Pierwszy cytat pochodzi z odpowiedzi udzielonej w trakcie rozmowy z Hansem-Georgiem Gadamerem. Odpowiedź dotyczyła kwestii występującego w dialogach

${ }^{47}$ „And by the incarnation is meant (according to the letter of Colossians, chapter 2) the presence of the theotes, the divine reality. And if you read only Colossians and not [any other text], you would assume that Christ is to be defined [...] as the optimal presence - the pleroma of parousia - of the divine in human being, while all other human beings have lesser presences of the divine, and are only aware that there is one person, the Christ, in whom there is pleroma of presence. And the theotes is not identified as a personal god, but - as you may say, in the Platonic sense - the presence of divine reality experienced in reality by the people who stand around and hear the Christ talk". E. Voegelin, Structures..., s. 372-373.

48 Aczkolwiek Voegelin zauważa, że w Nowym Testamencie termin theotes pojawia się jedynie dwa razy: jeszcze raz w Liście do Rzymian 1, 20: „Albowiem od stworzenia świata niewidzialne jego przymioty - wiekuista Jego potęga oraz bóstwo - stają się widzialne dla umysłu przez Jego dzieła, tak że nie mogą się wymówić od winy". Pomimo jedynie dwóch użyć terminu theotes Voegelin twierdzi, że to właśnie on oddaje istotę tego, kim był Chrystus. E. Voegelin, The Gospel..., s. 199.

49 „To the various translations as godhead, divinity, or deity, which carry the implication of personal God, I have preferred divine reality because it renders best the author's intention to denote nonpersonal reality which allows for degrees of participation in its fullness while remaining the God Beyond the In-Between of existence". Ibidem, s. 193. 
Platona terminu epekeina - ponad, transcendencja. Epekeina ani nie nie istnieje, ani istnieje - jest transcendentna wobec istnienia (w sensie istnienia na sposób wewnątrzświatowych bytów). Wywód o Jezusie zamykał wypowiedź Voegelina. Termin theotes wyraża więc właśnie przepływ obecności nie Boga (czyli Boga osobowego) w Pomiędzy świadomości, lecz nieosobowej, nie-egzystującej, boskości, którą Voegelin często nazywa otchłanią (abyss) boskości. Teraz można doprecyzować, że w Jezusie, a więc w świadomości Pomiędzy człowieka, objawiła się głębia boskości, otchłań boskości. Objawiła się właśnie taka, jaka (nie) jest- jako absolutna transcendencja, jako to, co nie będąc osobowe, wchodzi w relację z człowiekiem. Taki właśnie Bóg, zdaniem filozofa, nie może być Bogiem w unii dwóch zjednoczonych natur - głupstwem byłoby bowiem stwierdzenie, że radykalnie transcendentny Bóg jest osobą albo że zjednoczył się z tym, co istniejące.

Kwestia radykalnej transcendencji theotes wiąże się z metaleptyczną strukturą świadomości.

Problemy teofanii są współcześnie poważnie zaciemnione przez teologiczne, metafizyczne oraz ideologiczne nawarstwienia, dlatego nie będzie zbyteczne wskazanie sposobów zapobiegania typowym nieporozumieniom. [...] Wizja nie jest dogmatem, lecz wydarzeniem w rzeczywistości metaleptycznej, filozof może jedynie starać się zrozumieć ją tak, jak potrafi najlepiej ${ }^{50}$.

Jednakże jeżeli warunkiem zrozumienia sensu wizji Zmartwychwstałego jest odrzucenie metafizycznych ograniczeń, to czy stwierdzając, że wizja jest „wydarzeniem w rzeczywistości metaleptycznej", nie wikłamy się w metafizycznie ufundowaną filozofię świadomości? Jeśli zgodzimy się z Voegelinem, aby teofanię Chrystusa rozpatrywać w horyzoncie świadomości Pomiędzy, to musimy uznać, że: „W kontekście metaleptycznym Wcielenie jest rzeczywistością boskiej obecności w Jezusie [...] Natomiast Zmartwychwstanie odnosi się do Pawłowej wizji Zmartwychwstałego [...]"51. Wizja, jak i każde doświadczenie boskości (wydarzenie teofaniczne), nie tylko wydarza się w metaxy świadomości, lecz także nie odsyła do niczego poza tym, co przynależy do metaxy - treścią objawienia jest jego fakt, a nie coś innego niż sam fakt. Znaczy to, że wizja Zmartwychwstałego nie odsyła do rzeczywiście Zmartwychwstałego. Zmartwychwstanie nie jest rzeczywistością, faktycznym Zmartwychwstaniem Chrystusa w ciele, lecz rzeczywistością wizji w metaxy. Metaxy stanowi duchową przestrzeń świadomości, w której dochodzi do spotkania duchowej rzeczywistości boskości z ludzkim duchem. W metaxy nie ma żadnych danych, wrażeń zmysłowych. To rzeczywistość ducha ${ }^{52}$. To, co zmysłowe, jest późniejszą symboliczną ekspresją duchowego doświadczenia niematerialnej świadomości z niematerialną boską rzeczywistością. Jeśli przyjąć taką perspektywę, to nie można twierdzić, że Chrystus zmartwychwstał w ciele. Zmartwychwstanie bowiem jest wydarzeniem eschatologicznym, w którym objawiona zostaje prawda transfiguracji.

${ }^{50}$ E. Voegelin, Wizja..., s. 204.

${ }^{51}$ Ibidem, s. 205.

${ }^{52}$ E. Voegelin, The Beginng..., s. 180. „Any type of imaginery will do, so long as it conveys the awariress that the Word is not an utterance of immanent Man but emerges from the intangible point of the divine-human encounter in the Metaxy". 
Transfiguracja, chociaż paradoksalnie ma dotyczyć całej rzeczywistości, jest ruchem poza to, co materialne, ku temu, co niematerialne. Zmartwychwstanie w ciele zaś stoi $\mathrm{w}$ sprzeczności $\mathrm{z}$ tak pojętym ruchem transfiguracji. Musi być ono wydarzeniem w metaxy, wizją. Innymi słowy, według Voegelina, (w rozwiniętej postaci dyferencjacji świadomości) boskość nie pojawia się w zewnętrznym świecie, jawiąc się przez to, co materialne, lecz w duchowej rzeczywistości metaxy, której symbole (materialny wyraz) są jedynie ekspresją doświadczenia.

$\mathrm{Na}$ co więc wskazuje Voegelinowska chrystologia? Albo raczej: na co wskazuje odrzucenie koncepcji osobowego Boga wraz z rzeczywistością Zmartwychwstania (poza wizją św. Pawła)? Moim zdaniem owa filozoficzna wykładnia chrystologii wiąże się z tym, że Voegelin narzuca boskości pewne aprioryczne warunki możliwości jawienia się i bycia w ogóle. W wypadku Voegelina horyzontem warunkującym możliwość pojawienia się Boga nie jest ani byt jako causa sui, ani bycie, lecz boska transcendencja wraz z metaleptyczną strukturą świadomości. Dlaczego? Po doprowadzeniu dyferencjacji świadomości do stopnia, w którym dokonuje się adekwatne rozświetlenie rzeczywistości, okazuje się, że Bóg nie może wkroczyć do świata inaczej niż jako przepływ boskiej obecności w świadomości Pomiędzy człowieka, jako duchowy ruch, nie może również objawić niczego innego niż swój ruch. Chrześcijański mit eschatologiczny, w którym zmartwychwstanie w ciele traktuje się dosłownie, narusza zasadę dawania się jedynie w metaxy - eschatologiczna transfiguracja bowiem wydarzyłaby nie tylko w metaxy, wkraczałaby w sferę tego, co zmysłowe, a więc immanentne. W istocie rzeczy wydaje się, że według Voegelina chrześcijanie, oczekując rzeczywistego zmartwychwstania w ciele, zapominają, że to doświadczenie boskości w modi Początku (i końca) ma się dostosowywać do doświadczenia w modi Ponad. Tym samym kwestionuje się prymat i unikatowość metaxy - warunek metaleptycznej struktury świadomości odrzucający to, co materialne. Ponadto, gdyby Bóg udzielał się inaczej niż w metaxy, to pogwałciłby swoją transcendencję - warunek transcendencji/platońskiej epekeina. Koncepcja zjednoczenia dwóch natur wraz ideą osobowego Boga nie zgadzają się bowiem z nieosobowym wymiarem absolutnej transcendencji boskiej rzeczywistości. Nie może dojść do połączenia „nieegzystującej” otchłani z egzystującym w świecie i czasie człowiekiem. Stąd niemożliwość uznania tradycyjnie chrześcijańskiej hermeneutyki.

\section{Bibliografia}

Pismo Święte Starego i Nowego Testamentu, oprac. zespół biblistów polskich z inicjatywy benedyktynów tynieckich, A. Jankowski (red.), Poznań-Warszawa 1980.

Caringella P., Voegelin: Philosopher of Divine Presence [w:] Eric Voegelin's Significance for the Modern Mind, E. Sandoz (red.), Baton Roque 1991.

Gnoza polityczna, J. Skoczyński (red.), Kraków 1998.

Henry M., Eric Voegelin on Incarnate Christ, https://home.isi.org/eric-voegelin-incarnate-christ [dostęp 12.01.2016].

Hughes G., Mystery and Myth in the Philosophy of Eric Voegelin, Columbia, Missouri, 1993.

Kelly N.D., Początki doktryny chrześcijańskiej, tłum. J. Mrukówna, Warszawa 1998. 
McKnight S.A., Eric Voegelin's Search for Order in History, Baton Roque 1978.

Morrissey M.P., Consciousness and Transcendence: Theology of Eric Voegelin, Notre Dame 1994.

Niemeyer G., Christian Faith and Religion in Eric Voegelin's Work [w:] Within and Above Ourselves: Essays in Political Analysis, Wilmington 1996.

Problem ładu politycznego. Eseje o myśli Erica Voegelina, M.J. Czarnecki, A. Miętek (red.), Warszawa 2010.

Sandoz E., The Voegelinian Revolution: A Biographical Introduction, Baton Roque 1991.

Srigley R.D., Eric Voegelin's Platonic Theology: Philosophy of Consciousness and Symbolization in a New Perspective, New York 1991.

Stróżewski W., Ontologia, Kraków 2004.

Tilliete X., Chrystus filozofów. Prolegomena do chrystologii filozoficznej, tłum. A. Ziernicki, Kraków 1996.

Thompson W.M., Christ and Christianity in Israel and Revelation [w:] Voegelin's Israel and Revelation, W.M. Thompson, D.L. Morse (red.), Marquette 2000, s. 215-241.

Voegelin E., Anamnesis: On the Theory of History and Politics, Columbia 1990.

Voegelin E., The Gospel and Culture [w:] E. Voegelin, Published Essays 1966-1985, Baton Roque 1990.

Voegelin E., Order and History I: Israel and Revelation, Columbia 2001.

Voegelin E., Order and History IV: The Ecumenic Age, Columbia 2000.

Voegelin E., Structures of consciousness [w:] E. Voegelin, The Drama of Humanity and other Miscellaneous Papers 1939-1985, Columbia 2004.

Voegelin E., The Beginning and the Beyond: A Meditation on Truth [w:] E. Voegelin, What is History? And Other Late Unpublished Writings, Baton Rouge 1990.

Voegelin E., Wisdom and Magic of the Extreme: A Meditation [w:] E. Voegelin, Published Essays 1966-1985, Baton Roque 1990.

Voegelin E., Wizja Zmartwychwstatego u świętego Pawła, „Teologia Polityczna” 2012, nr 6, thum. M.J. Czarnecki.

Webb E., Eric Voegelin: Philosopher of History, Seattle, Washington, 1981. 